\title{
Construction and Utilization of Network Resources of Piano Impromptu Accompaniment Course
}

\section{Zifeng Tan}

School of Music and Dance, Lingnan Normal University, Zhanjiang 524000, Guangdong Province, China

Funding: This article is the current result of the 2017 Lingnan Normal College's teaching reform project "The Concept of "Return to Nature" and the Study of Piano Performance and Teaching Reform in Today's Social Quality Education" (project number: 1149618145)

\begin{abstract}
With the continuous deepening of the new curriculum reform in the field of higher education in our country, the piano impromptu accompaniment course has an increasing influence on students. In the current piano impromptu accompaniment course, teachers are influenced by many traditional concepts of music course education. Teachers mainly focus on singing and personal practice in the teaching process. In terms of teaching content, the selection of repertoire for students is relatively fixed and outdated, which causes students to feel monotonous, and reduces the quality of learning the piano impromptu accompaniment courses. That being said, this article thoroughly explores the construction and utilization of network resources in the process of piano improvisation, in order to improve the quality of education and teaching of piano impromptu courses in colleges and universities, and provide some valuable references for promoting the overall development of students.
\end{abstract}

Key words: Colleges and universities; Impromptu piano accompaniment; Network resources; Construction and utilization

Publication date: December, 2020

Publication online: 31 December, 2020

"Corresponding author: Zifeng Tan, 1357438642@ qq.com

The recent years have seen the continuous development of modern information technology. Realizing the effective integration of information technology and teaching content in the music curriculum is an important form to achieve the further reform of higher education. In addition, many college piano teachers are affected by traditional concepts of education in the teaching process, adopting the teaching method of "theoretical presentation + key demonstration" in the course. This rigid teaching model of piano impromptu accompaniment course has caused many students to think that learning about the course is boring. It is very important to innovate the teaching mode of piano impromptu accompaniment course and construct and apply properly the resources of network course.

\section{Status quo of the application of piano impromptu accompaniment course network resources}

\subsection{Insufficient attention paid by teachers}

Compared with the teaching mode of traditional piano impromptu accompaniment course, the teaching mode of online course is brand-new. To apply online course resources for teaching requires teachers to have a certain level of information technology applicable skills, as well as good profession. Only by the effective combination of the two, can we develop a more professional online course that is more in line with students' learning interests. However, many teachers are influenced by the traditional testoriented education concept in the current course of piano impromptu accompaniment courses in colleges and universities. They do not pay enough attention 
to the application of online course resources in piano improvisation accompaniment. In addition, some relatively elder teachers are not familiar with the application of information technology. Therefore, some teachers have inaccurate understanding of the characteristics of online course resources during the teaching process, which affects the application of online course resources in college piano impromptu accompaniment courses to a certain extent.

\subsection{Insufficient interest of students in learning}

Many students in the normal colleges did not pay enough attention to the knowledge of piano courses, influenced by the traditional test-oriented education concept. So, the music foundation of is not enough. In fact, most students have insufficient knowledge of piano impromptu courses. They think the piano impromptu accompaniment course is not the main professional course. Therefore, they did not attach great importance to the learning process. In addition, many students still find it difficult to get rid of the curriculum teaching model that teachers strictly controlled students in the middle school era in their daily learning activities. They did not fully accept the online course resources and lack of initiative in learning piano impromptu accompaniment. Finally, in terms of learning attitude, many students did not conduct enough in-depth research on the function of online course resources in daily learning. Students just click on the video without understanding the knowledge points of the course in the daily online courses.

\subsection{Insufficient ability of teachers}

In the development process of college piano impromptu course, teachers should continuously improve their personal qualities, follow the pace of education reform, and continuously strengthen communication with students in the process of teaching piano performance. Students cultivate more interests and hobbies in the new era. There are many new contents that teachers did not understand before. Under these circumstances, college teachers of piano impromptu accompaniment courses must continue to strengthen their professional skills, expand various new knowledge related to piano impromptu accompaniment, and promote the relationship with students. The common topics with students can shorten the distance between teachers and students without knowing it, which requires the teacher himself to be tolerant in the teaching process. They should constantly absorb new things, and actively listening to students' opinions on the piano improvisation course in learning activities, so as to realize the transformation of the teaching concept.

\section{Construction and utilization of network resources for piano impromptu accompa- niment course}

\subsection{Construction of curriculum in line of the interests of students}

From the above issues, it is not difficult for us to find that the premise of teachers to construct and apply the network resources is the students' interest in learning in the course of piano accompaniment courses in colleges and universities. In these circumstances, teachers of music courses in normal universities need to formulate targeted tasks of curriculum for students from a scientific perspective, designing and planning curriculum content. First of all, there is a certain difference between the piano foundation and knowledge learning ability of the students in the colleges, so the teacher should investigate the students' personal comprehensive learning ability in the learning process, and judge the learning ability and efficiency of piano impromptu accompaniment knowledge of students based on the main factors such as the basic music skills and psychological quality of the students. That being said, teachers should choose the corresponding online courses and targeted practice in the course, planning well in the construction of courses. For example, we can conclude from the current piano impromptu accompaniment course that many students have certain technical skills, but lack the ability to express emotions, so we should pay attention to the guidance of students' emotions in the process of selecting network resources. For example, students are assigned some daily listening homework on the teaching platform, so that students can feel the charm of piano accompaniment knowledge in the long-term musical admiration.

In addition, teachers of piano impromptu accompaniment courses in normal universities should deepen the effective integration between modern information technology and course content. For example, we can make full use of drama fragments which uses the piano music as the main background music in online teaching resources when cultivating 
students' music aesthetic ability. It will establish a great teaching environment to use the multimedia teaching platform to intuitively present the course content for students, so that students can develop good emotional empathy during the learning process. It will further cultivate students' sense of music and aesthetics ability.

\subsection{Enhancing personal skills and developing course content}

Teachers of piano impromptu accompaniment courses in normal colleges and universities should fully study the popular issues of various teaching modes supported by modern online resources. Combined with the course teaching content and the actual development needs of students, colleges should introduce some new teaching modes to improve the teaching quality of piano impromptu accompaniment courses to form a curriculum education system of singing and playing the piano by students themselves. For example, we can introduce the MOOC (Massive Open Online Courses) according to the content of the course in the teaching process to develop the micro-course teaching resources with our own characteristics. The audiovisual teaching content can more intuitively display the piano theory knowledge described by the teacher to students, so that college students can form a good immersive experience in the learning process. At the same time, piano impromptu teaching combined with modern information technology can also reflect students' dynamic changes, which is convenient for teachers to adjust professional teaching content in time to meet the learning needs of college students. The foundation for achieving high-quality development in colleges and universities lies in the conformity of students' vocational skills with the needs of the industry and the market. The vocational education model based on modern information technology can effectively improve students' learning ability of professional knowledge and make adjustments of students' abilities according to job needs at any time. Therefore, the development of premium the teaching content of micro-class is an important way to improve the quality of piano teaching in micro-class, based on the deepening of the integration of modern information technology and the teaching mode of traditional piano improvisation.

In addition, teachers should continuously improve the ability to use the network resources and modern information technology in the course of teaching. It is because the quality of curriculum education is ultimately determined by teachers and students. Although the online curriculum resources can assist the teaching process, the quality of class is ultimately depended on the actual teaching ability of teachers. Therefore, colleges and universities should strengthen the training for teachers to apply information technology, and encourage teachers to participate in various informatization teaching competitions. At the same time, college should add relevant assessment content about the ability of using information to the course evaluation standards.

\subsection{Forming content linkages to enhance the effectiveness of courses}

In the current stage of my country's higher music education, the piano foundation of non-music professional students in normal university is generally weak. To cope with this problem, we must make full use of the course network resources to reduce the difficulty of learning theoretical music theory. For example, in the beginning, we use Carl Czerny's works No. 599 and 849 as the students' practice repertoire, and guide students to download it or it is downloaded by teachers in advance to carry out practice activities.

In addition, the Multi-voice Music Writing tutorial edited by Zhang Li is used to guide students to learn the rules of chord arrangement. Students can find their favorite music clips in short online videos that they like on the Internet. Then teachers guide them to study the stave by joint exercises. This can mobilize everyone's enthusiasm and greatly enhance students' interest in learning the subject. With the help of online course resources, we can do a good job of downloading video, so as to help students clarify the course learning direction, and further improve the quality of education and teaching of piano impromptu accompaniment courses in normal universities.

\section{Conclusion}

To sum up, in the context of the continuous integration of information technology and higher education, the effective integration of network teaching resources and college piano impromptu course teaching activities can effectively overcome the shortcomings in the current stage of curriculum 
teaching. Compared with the traditional teaching modes in universities, the course teaching mode based on modern information technology can enable teachers to analyze the basic knowledge points or basic performance skills for students in a short 5-10 minutes teaching video. From the perspective of the form and function of the online course teaching mode, it is very suitable for the piano impromptu course with fragmented knowledge. Therefore, college music teachers should change the traditional "demonstration performance + course training" teaching mode in the course, and timely adopt network course resources to change the situation of piano impromptu accompaniment course, so as to lay a foundation for the further development of reforming higher education.

\section{References}

[1] Pan XF, Zhan SH. Innovative application of the teaching mode of piano impromptu accompaniment courses in normal universities under the vision of "Internet $+"[\mathrm{~J}]$. Journal of Honghe University, 2020, 18(06): 138-140.

[2] Liu LR. Discussion on the construction and utilization of network resources for piano improvisation accompaniment course[J]. Drama House, 2020(36):135-136. 